\title{
Galileo Reappraised
}

Published under the auspices of the

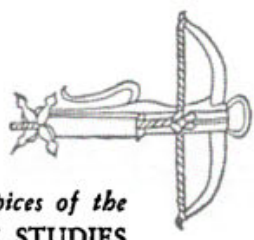
CENTER FOR MEDIEVAL AND RENAISSANCE STUDIES University of California, Los Angeles 
Contributions of the

UCLA CENTER FOR MEDIEVAL AND RENAISSANCE STUDIES

I. Medieval Secular Literature: Four Essays

2. Galileo Reappraised 
UCLA CENTER FOR

MEDIEVAL AND RENAISSANCE STUDIES

CONTRIBUTIONS: II

\section{Galileo Reappraised}

Edited by

CARLO L. GOLINO 
University of California Press Berkeley and Los Angeles, California

Cambridge University Press London, England

(C) 1966 by The Regents of the University of California Library of Congress Catalog Card Number: 66-1548s

Printed in the United States of America 